\title{
NITROGEN ACCUMULATION AND EXPORT BY COMMON BEAN AS A FUNCTION OF STRAW AND N SPLITTING IN NO-TILLAGE SYSTEM ${ }^{1}$
}

\author{
FÁBIO LUIZ CHECCHIO MINGOTTE ${ }^{2 *}$, FÁBIO TIRABOSCHI LEAL ${ }^{2}$, MARCELA MIDORI YADA DE ALMEIDA $^{3}$, \\ ORLANDO FERREIRA MORELLO ${ }^{2}$, TATIANA PAGAN LOEIRO DA CUNHA-CHIAMOLERA ${ }^{4}$, \\ LEANDRO BORGES LEMOS ${ }^{2}$
}

\begin{abstract}
Determining nitrogen (N) accumulation and export by common bean as a function of straw and of the splitting of this nutrient is very important, aiming at the management and sustainability of agricultural systems. This study aimed to determine the $\mathrm{N}$ accumulation and export by common bean as a function of Zea mays and Urochloa ruziziensis grass straw (maize, maize/U. ruziziensis intercropping and U. ruziziensis) and splitting of top-dressing $\mathrm{N}$ fertilization. The experiment was conducted in Jaboticabal-SP-Brazil, during the 2012/13 crop season, in a Red Eutrophic Oxisol (Eutrudox) in no-tillage under irrigation. The experimental design was a randomized block with split plots with four replicates, totaling 120 subplots sized in $25 \mathrm{~m}^{2}$ each. The plots consisted of the cropping systems prior to common bean: maize, maize/U. ruziziensis intercropping and $U$. ruziziensis. The subplots were composed of ten top-dressing $\mathrm{N}$ fertilization splitting schemes (NS) at the phenological stages $\mathrm{V}_{3}, \mathrm{~V}_{4}$ and $\mathrm{R}_{5}$ in different combinations. Common bean grain yield differs among cropping systems and as a function of top-dressed $\mathrm{N}$ split application. U. ruziziensis grass as single crop promotes greater $\mathrm{N}$ accumulation in common bean shoots compared to maize and its intercropping with U. ruziziensis grass. Regardless the cropping system, top-dressing $\mathrm{N}$ application in a single dose $\left(90 \mathrm{~kg} \mathrm{ha}^{-1}\right)$ at $\mathrm{V}_{4}$ leads to similar accumulations and exports to those found in the absence of $\mathrm{N}$ fertilization. Splitting schemes with $\mathrm{N}$ application at the $\mathrm{R}_{5}$ stage increase the exports of this nutrient by common bean in succession to maize and its intercropping with $U$. ruziziensis grass.
\end{abstract}

Keywords: Phaseolus vulgaris. Plant mineral nutrition. Conservation agriculture.

\section{ACÚMULO E EXPORTAÇÃO DE NITROGÊNIO PELO FEIJOEIRO EM FUNÇÃO DA PALHADA E DO SEU PARCELAMENTO NO SISTEMA PLANTIO DIRETO}

\begin{abstract}
RESUMO - Determinar o acúmulo e a exportação de nitrogênio $(\mathrm{N})$ pelo feijoeiro em função da palhada e do seu parcelamento é importante visando o manejo e a sustentabilidade dos sistemas agrícolas. O objetivo com esse trabalho foi determinar o acúmulo e a exportação de $\mathrm{N}$ pelo feijoeiro cultivado sob palhada de milho (Zea mays) e braquiária (Urochloa ruziziensis) exclusivos ou em consórcio e em função do parcelamento da adubação nitrogenada em cobertura. $\mathrm{O}$ experimento foi conduzido em Jaboticabal-SP-Brasil, durante a safra 2012/13, num Latossolo Vermelho eutrófico típico, sob área irrigada no sistema plantio direto. O delineamento experimental foi em blocos ao acaso com parcelas subdivididas com quatro repetições, totalizando 120 subparcelas dimensionadas em $25 \mathrm{~m}^{2}$ cada. As parcelas foram constituídas pelos sistemas de cultivo antecessores ao feijoeiro: milho, milho consorciado com braquiária e braquiária. As subparcelas foram compostas por dez parcelamentos da adubação nitrogenada de cobertura (PN) estádios fenológicos $V_{3}, V_{4}$ e $R_{5}$ em diferentes combinações. A produtividade de grãos do feijoeiro difere entre os sistemas de cultivo e em função do parcelamento do $\mathrm{N}$ em cobertura. $\mathrm{O}$ cultivo exclusivo de braquiária proporciona maiores acúmulos de $\mathrm{N}$ na parte aérea do feijoeiro comparado ao milho e seu consórcio com braquiária. Independentemente do sistema de cultivo, a aplicação de $\mathrm{N}$ em cobertura em dose única de $90 \mathrm{~kg} \mathrm{ha}^{-1}$ em $\mathrm{V}_{4}$ (terceiro trifólio) proporciona acúmulos e exportações semelhantes àqueles na ausência da adubação nitrogenada. Os parcelamentos com aplicação de $\mathrm{N}$ em cobertura no estádio $\mathrm{R}_{5}$ (pré-florescimento) incrementa as exportações desse nutriente no feijoeiro em sucessão ao milho e seu consórcio com braquiária.
\end{abstract}

Palavras-chave: Phaseolus vulgaris. Nutrição mineral de plantas. Agricultura conservacionista.

\footnotetext{
${ }^{*}$ Corresponding author

${ }^{1}$ Received for publication in $02 / 22 / 2020$; accepted in $10 / 19 / 2020$.

Paper extracted from the doctoral thesis of the first author.

${ }^{2}$ Department of Agricultural Sciences, Universidade Estadual Paulista, Jaboticabal, SP, Brazil; fabio.mingotte@unesp.br - ORCID: 00000003-0383-7802, lealft@bol.com.br - ORCID: 0000-0002-4724-6601, ofmorello@hotmail.com - ORCID: 0000-0002-7998-043X, leandro.lemos@unesp.br-ORCID: 0000-0003-1781-1267.

${ }^{3}$ Department of Soil, Faculdades ITES, Taquaritinga, SP, Brazil; marcelayada@gmail.com - ORCID: 0000-0002-6101-7258.

${ }^{4}$ Department of Agronomy, Universidad de Almería, Almería, Spain; tatiana.pagan@hotmail.com - ORCID: 0000-0002-3096-608X.
} 


\section{INTRODUCTION}

The no-tillage system (NTS) is largely responsible for increasing the sustainability of agriculture in the tropics. Practices such as minimal soil disturbance, maintenance of straw, crop rotation and permanence of living roots substantially contribute for the agricultural systems to remain productive for longer periods. However, the NTS faces difficulties with the formation and maintenance of straw in tropical regions, especially in climates with hot and rainy summer and dry winter (BUTENSCHOEN; SCHEU; EISENHAUER, 2011). Under these conditions, there is a high rate of decomposition of plant residues that, combined with the difficulty for their production in the off-season (autumn and winter), compromises this system.

Thus, the cultivation of grasses, especially in the summer, has been suggested to promote large quantity of straw and greater persistence, due to the high carbon:nitrogen $(\mathrm{C} / \mathrm{N})$ ratio (AMARAL et al., 2016; FLÔRES et al., 2017). Hence, the inclusion of $U$. ruziziensis species in agricultural systems, cultivated as single crops or intercropped, can favor the sustainability of the NTS. U. ruziziensis grass has been intercropped mainly with maize due to the profit with grain production and improvement of the soil environment. The benefits of $U$. ruziziensis grass are related to high adaptability to acidic, low-fertility soils, nutrient cycling, better $\mathrm{N}$ use, reduction of diseases such as white mold, dry root rot and rot by Fusarium and Rhizoctonia (KLUTHCOUSKI et al., 2013).

In this context, common bean (Phaseolus vulgaris L.) is the main crop in rotation in the NTS in the off-season (autumn-winter), especially in irrigated areas in the Central-South region of Brazil, and can be produced in succession to maize, to the maize/U. ruziziensis intercropping or to $U$. ruziziensis grass as single crop. Common bean has great nutritional, economic and social importance, because it is the main source of proteins in the Brazilian diet, and it is cultivated by small to large producers with different technological levels. Brazil is the largest common bean producer in the world, with a cultivated area of 2.9 million hectares, reaching grain yield of around $1,089 \mathrm{~kg} \mathrm{ha}^{-1}$ (CONAB, 2020). However, knowledge on how the straw of previous grasses influences $\mathrm{N}$ accumulation and export by this crop still needs to be better understood.

$\mathrm{N}$ supply by the straw may occur at different release rates during its decomposition due to the different amounts of plant material deposited on the soil, to $\mathrm{C} / \mathrm{N}$ ratios, and to the lignin and cellulose contents (MBUTHIA et al., 2015). Hence, the inclusion of $U$. ruziziensis grass in the cropping systems usually results in straw with higher dry biomass, but lower $\mathrm{C} / \mathrm{N}$ ratio. On the other hand, it is common for maize straw to have higher $\mathrm{C} / \mathrm{N}$ ratio and lower dry biomass (AMARAL et al., 2016). In addition, studies suggest the effect of exudates of the roots of this forage on $\mathrm{N}$ cycling, suppressing the processes of nitrification and leaching (GOPALAKRISHNAN et al., 2009).

$\mathrm{N}$ is the most required nutrient by common bean, which needs 30 to $45 \mathrm{~kg}$ of $\mathrm{N}$ for every 1,000 $\mathrm{kg}$ of grains (OLIVEIRA; THUNG, 1988). Due to the shallow root system and short cycle, the requirement for readily available $\mathrm{N}$ during the initial stages is higher for this crop. In addition, factors such as the high export of this nutrient to the grains $50 \%$ of $\mathrm{N}$ absorbed is exported (PEREZ et al., 2013), insufficiency of biological $\mathrm{N}$ fixation (FIGUEIREDO et al., 2016), and $\mathrm{N}$ losses by volatilization and leaching also cause large amounts of the nutrient to be required via fertilization. The use of $\mathrm{N}$-fertilizers in tropical soils favor $\mathrm{N}$ losses, increasing environmental risks, such as groundwater pollution and GEE emission (SOUZA; FERREIRA, 2017). For these reasons, the adequate management of $\mathrm{N}$ fertilization becomes fundamental for the success of crops because of these factors, associated with the complexity of $\mathrm{N}$ dynamics in soil.

Thus, splitting of $\mathrm{N}$ fertilization is recommended for the bean crop in order to reduce $\mathrm{N}$ losses by volatilization and, mainly, by leaching (AMBROSANO, 1997). However, it is important to point out that this recommendation was established for conventional soil tillage systems, and there is a lack of information on N management in NTS for this crop. In the NTS, immobilization may be greater than mineralization, especially in the first years of adoption of this system (FAGERIA, 2014), which can limit the yield due to the insufficient application of $\mathrm{N}$ during the initial stages of the crop (MAI et al., 2003). Thus, early $\mathrm{N}$ fertilization at pre-sowing or sowing may be an alternative, but this practice may increase the processes of leaching and salinization of seeds (CERETTA et al., 2002). Thus, splitting the applications along the common bean cycle can be more viable, especially at earlier phenological stages. However, there are few studies evaluating N splitting at the phenological stages of the crop and its effects on plant nutrition.

Therefore, with the hypotheses that the $\mathrm{N}$ supply by the straw to the common bean in succession has different patterns of release of this nutrient during the decomposition of plant residues and that the $\mathrm{N}$ immobilization processes in the NTS in the first years of adoption of this system can be more intense, requiring alterations in the moments of top-dressing $\mathrm{N}$ application, the present study aimed to determine the $\mathrm{N}$ accumulation and export by common beans as a function of grass straw (maize, maize/U. ruziziensis intercropping and $U$. ruziziensis) and of the splitting of top-dressing $\mathrm{N}$ fertilization. 


\section{MATERIAL AND METHODS}

The experiment was conducted in the 2012/13 agricultural year at the Farm of Teaching, Research and Extension of the São Paulo State University UNESP/FCAV, Jaboticabal, SP, Brazil ( $21^{\circ} 14^{\prime} \mathrm{S}$; $48^{\circ} 17^{\prime} \mathrm{W}$; average altitude of 586 meters) in soil classified as Latossolo Vermelho eutrófico típico, that is, Red Eutrophic Oxisol (Eutrudox), with gently undulating relief under Cerrado vegetation (SOIL SURVEY STAFF, 2014), of clayey texture, with 533 $\mathrm{g} \mathrm{kg}^{-1}$ of clay, $193 \mathrm{~g} \mathrm{~kg}^{-1}$ of silt and $274 \mathrm{~g} \mathrm{~kg}^{-1}$ of sand. According to Köppen's classification, the climate of this region is Aw, humid tropical with rainy season in the summer and dry season in the winter, and average annual precipitation of $1425 \mathrm{~mm}$ (ALVARES et al., 2013). The climatic information recorded during the experiment is shown in Figure 1.

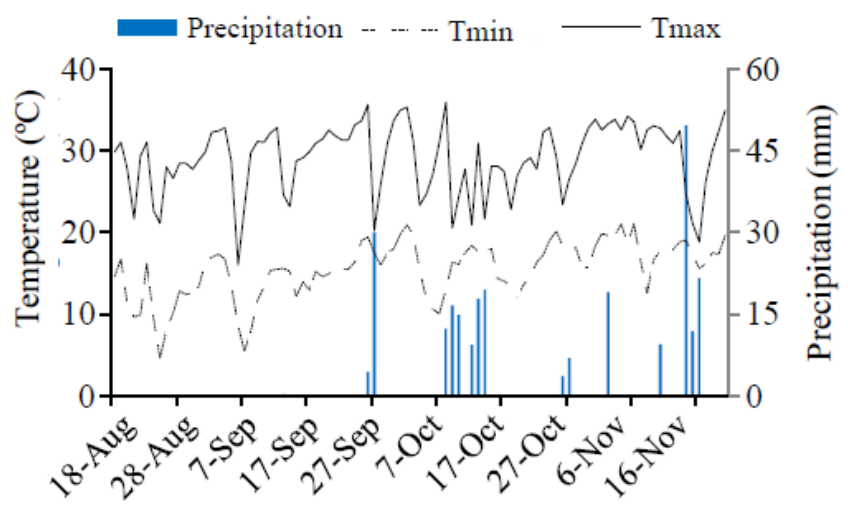

Figure 1. Cumulative precipitation, maximum and minimum temperature, and the average for every 5 days during 2012/13 winter crop season of common bean.

The experimental area was characterized by the adoption of the NTS since the summer of the 2008/09 agricultural year (JARDIM, 2013; MINGOTTE et al., 2020), implemented through the scarification of the soil, followed by plowing with disc plow and two passes of leveling harrow and, subsequently, using along the period the following successions: maize and common bean; maize/U. ruziziensis intercropping and common bean; and $U$. ruziziensis and common bean. The grasses were cultivated during the summer and the common bean under irrigation during the winter-spring. Prior to NTS implementation, the area had been maintained for at least 15 years under conventional system with cultivation of maize, common bean, soybean and rice, alternated with some periods of fallow.

Before common bean sowing, soil samples were collected in the area and soil analysis in the 0-20 cm layer was performed to evaluate soil fertility following as methodologies described by Raij et al. (2001). The chemical attributes were: hydrogen potential $\left(\mathrm{pH} \quad \mathrm{CaCl}_{2}\right): 5.3$; organic matter $=$ $28 \mathrm{~g} \mathrm{dm}^{-3}$; phosphorus $(\mathrm{P}-$ resin $)=126 \mathrm{mg} \mathrm{dm}^{-3}$; potential acidity $(\mathrm{H}+\mathrm{Al})=34 \mathrm{mmol}_{\mathrm{c}} \mathrm{dm}^{-3}$; potassium $(\mathrm{K})=5.4 \mathrm{mmol}_{\mathrm{c}} \mathrm{dm}^{-3}$; $\operatorname{calcium}(\mathrm{Ca})=36$ $\mathrm{mmol}_{\mathrm{c}} \mathrm{dm}^{-3}$; magnesium $(\mathrm{Mg})=20 \mathrm{mmol}_{\mathrm{c}} \mathrm{dm}^{-3}$; cationic exchange capacity $(\mathrm{CEC})=95 \mathrm{mmol}_{\mathrm{c}} \mathrm{dm}^{-3}$ and base saturation $(\mathrm{BS})=64 \%$.

The experimental design was randomized blocks in a split-plot scheme, with four replicates.
The plots consisted of three cropping systems (CS) prior to the irrigated common bean in NTS: maize, maize intercropped with Urochloa ruziziensis, and $U$. ruziziensis. The subplots consisted of ten $\mathrm{N}$ fertilization splitting schemes (NS) (total dose $=90$ $\mathrm{kg} \mathrm{ha}{ }^{-1}$ of $\mathrm{N}$ ) at the phenological stages $\mathrm{V}_{3}$ (formation of the first trifoliate leaf), $\mathrm{V}_{4}$ (presence of third trifoliate leaf) and $\mathrm{R}_{5}$ (pre-flowering) $\left(\mathrm{V}_{3}+\mathrm{V}_{4}+\right.$ $\mathrm{R}_{5}$ ), respectively: $00+00+00$ (control); $00+90+00$; $30+60+00 ; \quad 60+30+00 ; \quad 30+00+60 ; \quad 60+00+30 ;$ $00+60+30 ; 45+45+00 ; 00+45+45 ;$ and $45+00+45$. The $\mathrm{N}$ total dose $\left(90 \mathrm{~kg} \mathrm{ha}^{-1}\right)$ referred to the class of high response as it is an irrigated crop and cultivated after grasses, following the recommendations of Ambrosano et al. (1997). In total, the experiment had 120 subplots (experimental units). Each subplot consisted of ten common bean rows with length of $5 \mathrm{~m}$, considering for evaluations the eight central rows, disregarding $0.5 \mathrm{~m}$ on each side. $\mathrm{N}$ was applied manually in the form of urea according to each treatment in a continuous line at $10 \mathrm{~cm}$ away from common bean row, incorporated by a $15 \mathrm{~mm}$ water depth through irrigation (VIERO et al. 2015).

The grasses were sown on December 07, 2012. Maize (single hybrid DKB $390 \mathrm{YG}^{\circledR}$ ), both as single crop and intercropped, was sown at spacing of $0.90 \mathrm{~m}$ between rows, with density of 66,000 plants $\mathrm{ha}^{-1}$. In the intercropping, $U$. ruziziensis grass (Urochloa ruziziensis cv. 'Comum') was sown simultaneously to maize, between rows, in a double 
row with spacing of $0.22 \mathrm{~m}$, by distributing $7.5 \mathrm{~kg}$ of seeds $\mathrm{ha}^{-1}$. In the maize crop, fertilizations were based on the recommendations of Raij and Cantarella (1997) considering the analysis of soil fertility. Fertilization at sowing for maize and for the intercropping was performed with the dose of $160 \mathrm{~kg} \mathrm{ha}^{-1}$ of the commercial formulation 08-28-16. As top-dressing, both maize and the intercropping received $80 \mathrm{~kg} \mathrm{ha}^{-1}$ of $\mathrm{N}$ via 20-00-20 formulation at $\mathrm{V}_{4}$ and $112 \mathrm{~kg} \mathrm{ha}^{-1}$ of $\mathrm{N}$ via urea at $\mathrm{V}_{6-7}$. No fertilizations were performed for $U$. ruziziensis grass as single crop.

Maize (single crop and intercropped) was mechanically harvested on June 4, 2013 and the total area of the experiment was desiccated with the herbicide glyphosate $\left(1,800 \mathrm{~g} \mathrm{ha}^{-1}\right.$ of a.i.) at 30 days before sowing the common bean.

Common bean was sown on August 8, 2013, using the cultivar IPR 139 (Juriti Claro), which has upright, indeterminate growth habit (type II), normal cycle and grains of the 'Carioca' commercial group, at spacing of $0.45 \mathrm{~m}$ between rows, with 12.5 seeds per meter of furrow. The emergence of plants occurred on August 12, 2013. Seeds were treated with carbendazim + thiram (45 g and $105 \mathrm{~g}$ of a.i. per $100 \mathrm{~kg}$ of seeds, respectively) and thiamethoxam (140 $\mathrm{g}$ of a.i. per $100 \mathrm{~kg}$ of seeds). Fertilization at sowing consisted of $300 \mathrm{~kg} \mathrm{ha}^{-1}$ of the 04-15-08 formulation, considering the soil analysis and recommendations of Ambrosano et al. (1997). The herbicide fluazifop-p-butyl (75 g a.i. ha $\left.{ }^{-1}\right)$ was applied at 15 days after emergence (DAE) of common bean. Pests and diseases were controlled with applications of azoxystrobin (40 $\mathrm{g}$ a.i. ha $\left.{ }^{-1}\right)$, lambda-cyhalothrin (30 g a.i. ha $\left.{ }^{-1}\right)$ and abamectin (5.4 g a.i. $\mathrm{ha}^{-1}$ ) between 20 and $25 \mathrm{DAE}$, thiamethoxam (14.1 g a.i. $\left.\mathrm{ha}^{-1}\right)$ and lambdacyhalothrin (10.6 g a.i. $\left.\mathrm{ha}^{-1}\right)$ at 40 DAE. Pyraclostrobin ( $75 \mathrm{~g}$ a.i. ha $\left.{ }^{-1}\right)$, deltamethrin (3.5 g a.i. $\left.\mathrm{ha}^{-1}\right)$ and triazofos (122 g a.i. ha $\left.{ }^{-1}\right)$ were applied at 65 DAE. At 90 DAE, plants present in the useful area of each subplot were manually uprooted (November 6, 2013), and mechanically threshed. The crop was irrigated along the entire cycle, with water depths between 10 and $50 \mathrm{~mm}$ every 4 to 6 days, according to the recommendations of Pavani, Lopes and Galbeiro (2008).

At the full flowering stage $\left(\mathrm{R}_{6}\right)$ (October 2, 2013), plant population was determined by counting the plants contained in two rows of $5 \mathrm{~m}$ and collecting 10 plants per experimental unit. The material (shoots) was washed with distilled water, dried in a forced air ventilation oven at $60-70{ }^{\circ} \mathrm{C}$ for $72 \mathrm{~h}$, weighed, and then the data were transformed to $\mathrm{kg} \mathrm{ha}^{-1}$ of dry mass. The transformation of the dry mass of 10 plants to produce dry mass per hectare was carried out according to Equation 1:

$$
\mathrm{SDM}=\mathrm{SDM}_{10}+\mathrm{POP} / 5 \times 1000
$$

In which:

SDM: Shoot dry mass in the total area $\left(\mathrm{kg} \mathrm{ha}^{-1}\right)$; $\mathrm{SDM}_{10}$ : Shoot dry mass of ten plants per experimental unit $(\mathrm{g})$;

POP: Plant population (plants $\mathrm{ha}^{-1}$ ).

Subsequently, the harvested material was ground and subjected to chemical analysis, to determine the $\mathrm{N}$ concentrations through sulfuric acid digestion. These results were then used to estimate the accumulated amounts of these nutrients per area, according to the treatments and to Equation 2:

$$
\mathrm{EXP}=(\mathrm{SDM} \times \mathrm{N} \text { concentration }) / 1000
$$

In which:

EXP: Nitrogen export per area $\left(\mathrm{kg} \mathrm{ha}^{-1}\right)$;

SDM: Shoot dry mass in the total area $\left(\mathrm{kg} \mathrm{ha}^{-1}\right)$; $\mathrm{N}$ concentration: Nitrogen concentrations in the shoot dry mass of ten plants.

Shoot dry mass per area and export per area were estimated by following the methodology of Soratto et al. (2013b) and Leal et al. (2019). After physiological maturity $\left(R_{9}\right)$ (November 1, 2013), harvest was carried out in the useful area of each plot and grain yield was determined, in $\mathrm{kg} \mathrm{ha}^{-1}(13 \%$ moisture content). Grain samples were collected, oven-dried at $60-70{ }^{\circ} \mathrm{C}$, ground and subjected to the same analyses and determinations described above. These results were used to estimate the quantities $\mathrm{N}$ exported per area.

The statistical analysis was performed using the Sisvar ${ }^{\circledR}$ Software (FERREIRA, 2011). The data were subjected to analysis of variance by $\mathrm{F}$ test $(p<0.05)$ and means were compared by Tukey test $(p<0.05)$. When $F$ was significant for the CS $x$ NS interaction, it was further analyzed.

\section{RESULTS AND DISCUSSION}

The shoot dry mass production of common bean was influenced only by the previous cropping systems, with the highest value obtained after the systems with $U$. ruziziensis grass (Table 1). 
Table 1. Shoot dry mass (SDM), $\mathrm{N}$ concentration and accumulation in the shoots, grain yield, $\mathrm{N}$ concentration and export by common bean (cv. IPR 139) as a function of the splitting of $\mathrm{N}$ in succession to maize as single crop, to the intercropping of maize $+U$. ruziziensis and $U$. ruziziensis as single crop, in no-tillage system, Jaboticabal-SP, 2012/13 agricultural year $^{(1)}$.

\begin{tabular}{|c|c|c|c|c|c|c|}
\hline \multirow{2}{*}{ Treatments } & SDM & \multicolumn{2}{|c|}{---------- Shoots ---------- } & Grain yield & $\begin{array}{l}\text { N concentration } \\
--- \text { Grain -- }\end{array}$ & $\mathrm{N}$ export \\
\hline & $\mathrm{kg} \mathrm{ha}^{-1}$ & $\mathrm{~g} \mathrm{~kg}^{-1}$ & $\mathrm{~kg} \mathrm{ha}^{-1}$ & $\mathrm{~kg} \mathrm{ha}^{-1}$ & $\mathrm{~g} \mathrm{~kg}^{-1}$ & $\mathrm{~kg} \mathrm{ha}^{-1}$ \\
\hline Cropping system & & & & & & \\
\hline Maize & $4438 \mathrm{~b}$ & $12.7 \mathrm{~b}$ & $56.5 \mathrm{~b}$ & 3157 & $32.0 \mathrm{a}$ & 87.9 \\
\hline Intercropping & $4626 \mathrm{ab}$ & $11.8 \mathrm{c}$ & $54.9 \mathrm{~b}$ & 3167 & $31.1 \mathrm{~b}$ & 85.8 \\
\hline U. ruziziensis & $4775 \mathrm{a}$ & $15.4 \mathrm{a}$ & $73.6 \mathrm{a}$ & 3029 & $32.6 \mathrm{a}$ & 85.9 \\
\hline Tukey LSD & 301.20 & 0.83 & 6.94 & 188.63 & 0.76 & 3.68 \\
\hline $\mathrm{CV}(\%)$ & 9.5 & 9.13 & 16.4 & 8.8 & 3.5 & 6.2 \\
\hline $\mathrm{N}_{\text {splitting }}^{2}$ & & & & & & \\
\hline $00+00+00$ & 4514 & $12.8 \mathrm{ab}$ & $58.1 \mathrm{abc}$ & $2929 \mathrm{e}$ & 32.5 & $82.7 \mathrm{c}$ \\
\hline $00+90+00$ & 4699 & $14.5 \mathrm{a}$ & $68.3 \mathrm{a}$ & $2939 \mathrm{de}$ & 32.3 & $82.5 \mathrm{c}$ \\
\hline $30+60+00$ & 4727 & $13.9 \mathrm{a}$ & $66.3 \mathrm{ab}$ & $3305 \mathrm{a}$ & 30.8 & $88.3 \mathrm{abc}$ \\
\hline $60+30+00$ & 4787 & $14.0 \mathrm{a}$ & $67.1 \mathrm{ab}$ & 3031 cde & 32.0 & $84.3 \mathrm{bc}$ \\
\hline $30+00+60$ & 4760 & $13.5 \mathrm{a}$ & $64.5 \mathrm{ab}$ & $3298 \mathrm{ab}$ & 32.1 & $91.9 \mathrm{a}$ \\
\hline $60+00+30$ & 4468 & $13.7 \mathrm{a}$ & $61.3 \mathrm{abc}$ & $3132 \mathrm{bc}$ & 31.8 & $86.5 \mathrm{abc}$ \\
\hline $00+60+30$ & 4575 & $13.6 \mathrm{a}$ & $61.9 \mathrm{abc}$ & $3110 \mathrm{~cd}$ & 32.2 & $87.2 \mathrm{abc}$ \\
\hline $45+45+00$ & 4541 & $11.6 \mathrm{~b}$ & $52.5 \mathrm{c}$ & 3057 cde & 31.8 & $84.6 \mathrm{bc}$ \\
\hline $00+45+45$ & 4554 & $12.9 \mathrm{ab}$ & $58.8 \mathrm{abc}$ & $3202 \mathrm{abc}$ & 32.7 & $91.1 \mathrm{ab}$ \\
\hline $45+00+45$ & 4506 & $12.8 \mathrm{ab}$ & $57.9 \mathrm{bc}$ & $3172 \mathrm{abc}$ & 31.1 & $85.8 \mathrm{abc}$ \\
\hline Tukey LSD & 472.43 & 1.79 & 10.41 & 171.21 & 2.22 & 7.23 \\
\hline CV $(\%)$ & 7.7 & 10.1 & 13.7 & 4.1 & 5.2 & 6.3 \\
\hline F test & & & & & & \\
\hline $\mathrm{CS}$ & $5.92 *$ & $94.97 * *$ & $42.31 * *$ & $3.13^{\mathrm{NS}}$ & $18.93 * *$ & $2.01^{\mathrm{NS}}$ \\
\hline NS & $1.31^{\mathrm{NS}}$ & $4.51^{* *}$ & $4.83 * *$ & $12.59 * *$ & $1.56^{\mathrm{NS}}$ & $4.21 * *$ \\
\hline $\mathrm{CS} \times \mathrm{NS}$ & $0.98^{\mathrm{NS}}$ & $3.12 * *$ & $2.32 * *$ & $5.42^{* *}$ & $0.97^{\mathrm{NS}}$ & $2.19 * *$ \\
\hline
\end{tabular}

${ }^{1}$ Means followed by the same letter do not differ by Tukey test $(\mathrm{p}<0.05) . * *(\mathrm{p}<0.05)$ and ${ }^{\mathrm{NS}}$ (not significant) by $\mathrm{F}$ test, respectively. ${ }^{2}$ Quantity of $\mathrm{N}$ applied as top-dressing at the stages $\mathrm{V}_{3}, \mathrm{~V}_{4}$ and $\mathrm{R}_{5}$ of common bean, respectively.

Such superiority was related to the highest $\mathrm{N}$ concentrations in the shoots of common bean when cultivated under the straw of only this grass. This nutrient is related to the increase in net photosynthesis, which leads to increments in the dry mass production of the common bean (FAGERIA; MELO; OLIVEIRA, 2013). The absence of topdressing $\mathrm{N}$ and the splitting schemes with $\mathrm{N}$ dose of
$90 \mathrm{~kg} \mathrm{ha}$ applied entirely at the stage $\mathrm{V}_{4}$ $(00+90+00)$ or with part at $\mathrm{V}_{3}$ and $\mathrm{V}_{4}(30+60+00$; $60+30+00 ; 45+45+00)$, as well as at $\mathrm{V}_{4}$ and $\mathrm{R}_{5}$ $(00+45+45)$, resulted in higher $\mathrm{N}$ contents in the shoots when cultivated after $U$. ruziziensis grass as single crop compared to maize as single crop or intercropped (Table 2).

Table 2. Analysis of the interaction between cropping system (CS) and top-dressing nitrogen splitting (NS) for its concentration in the shoots of common bean (cv. IPR 139), at the phenological stage $\mathrm{R}_{6}$, cultivated in the no-tillage system, Jaboticabal-SP, 2012/13 agricultural year ${ }^{(1)}$.

\begin{tabular}{cccc}
\hline \multirow{2}{*}{ Treatments } & \multicolumn{3}{c}{ N concentration in the shoots $\left(\mathrm{g} \mathrm{kg}^{-1}\right)$} \\
\cline { 2 - 4 } & Maize & Intercropping & U. ruziziensis \\
\hline N splitting $^{2}$ & & & $16.4 \mathrm{abA}$ \\
$00+00+00$ & $12.0 \mathrm{aB}$ & $10.1 \mathrm{bcB}$ & $18.1 \mathrm{aA}$ \\
$00+90+00$ & $12.8 \mathrm{aB}$ & $12.6 \mathrm{abB}$ & $16.6 \mathrm{abA}$ \\
$30+60+00$ & $12.6 \mathrm{aB}$ & $12.5 \mathrm{abB}$ & $16.7 \mathrm{abA}$ \\
$60+30+00$ & $13.4 \mathrm{aB}$ & $12.1 \mathrm{abB}$ & $14.9 \mathrm{bcA}$ \\
$30+00+60$ & $11.9 \mathrm{aB}$ & $13.8 \mathrm{aAB}$ & $14.7 \mathrm{bcA}$ \\
$60+00+30$ & $13.5 \mathrm{aA}$ & $13.0 \mathrm{abA}$ & $14.6 \mathrm{bcA}$ \\
$00+60+30$ & $13.3 \mathrm{aA}$ & $12.8 \mathrm{abA}$ & $14.2 \mathrm{bcA}$ \\
$45+45+00$ & $11.6 \mathrm{aB}$ & $9.0 \mathrm{cC}$ & $15.1 \mathrm{abcA}$ \\
$00+45+45$ & $12.3 \mathrm{aB}$ & $11.3 \mathrm{abcB}$ & $13.1 \mathrm{cAB}$ \\
$45+00+45$ & $14.1 \mathrm{aA}$ & $11.3 \mathrm{abcB}$ & \\
\hline
\end{tabular}

${ }^{1}$ Means followed by different letters, uppercase in the row and lowercase in the column, differ by Tukey test $(\mathrm{p}<0.05)$. ${ }^{2}$ Quantity of $\mathrm{N}$ applied as top-dressing in common bean at the phenological stages $\mathrm{V}_{3}$ (formation of first trifoliate leaf), $\mathrm{V}_{4}$ (presence of third trifoliate leaf) and $\mathrm{R}_{5}$ (pre-flowering), respectively. 
In addition, under all types of straw, there were no differences in the $\mathrm{N}$ content in the absence and presence of top-dressing $\mathrm{N}$ fertilization, except for the splitting schemes $45+45+00$ and $45+00+45$, which resulted in lower $\mathrm{N}$ content after maize/ $U$. ruziziensis intercropping and $U$. ruziziensis grass as single crop, respectively. As a consequence of the higher dry mass productions and $\mathrm{N}$ contents in the shoots, there was higher $\mathrm{N}$ accumulation in the common bean under straw of $U$. ruziziensis grass as single crop, especially in the absence of top-dressing $\mathrm{N}$ and in the treatments $00+90+00,30+60+00$, $60+30+00,30+00+60$ and $00+45+45$ (Table 3 ), which did not differ from one other in terms of $\mathrm{N}$ accumulation.

Table 3. Analysis of the interaction between cropping system (CS) and top-dressing nitrogen splitting (NS) for its accumulation in the shoots of common bean (cv. IPR 139), at the phenological stage $\mathrm{R}_{6}$, cultivated in the no-tillage system, Jaboticabal-SP, 2012/13 agricultural year ${ }^{(1)}$.

\begin{tabular}{|c|c|c|c|}
\hline \multirow{2}{*}{ Treatments } & \multicolumn{3}{|c|}{$\mathrm{N}$ accumulation in the shoots $\left(\mathrm{kg} \mathrm{ha}^{-1}\right)$} \\
\hline & Maize & Intercropping & U. ruziziensis \\
\hline $\mathrm{N}$ splitting ${ }^{2}$ & & & \\
\hline $00+00+00$ & $52.5 \mathrm{aB}$ & $45.3 \mathrm{bcB}$ & $76.6 \mathrm{abcA}$ \\
\hline $00+90+00$ & $58.1 \mathrm{aB}$ & $58.4 \mathrm{abcB}$ & $88.5 \mathrm{aA}$ \\
\hline $30+60+00$ & $55.6 \mathrm{aB}$ & $58.4 \mathrm{abcB}$ & $85.0 \mathrm{abA}$ \\
\hline $60+30+00$ & $67.4 \mathrm{aAB}$ & $56.4 \mathrm{abcB}$ & $77.5 \mathrm{abcA}$ \\
\hline $30+00+60$ & $54.2 \mathrm{aA}$ & $66.5 \mathrm{aAB}$ & $72.6 \mathrm{abcA}$ \\
\hline $60+00+30$ & $55.6 \mathrm{aA}$ & $59.9 \mathrm{abA}$ & $68.5 \mathrm{bcA}$ \\
\hline $00+60+30$ & $57.7 \mathrm{aA}$ & $59.5 \mathrm{abA}$ & $68.7 \mathrm{bcA}$ \\
\hline $45+45+00$ & $50.8 \mathrm{aB}$ & $40.8 \mathrm{cB}$ & $66.0 \mathrm{cA}$ \\
\hline $00+45+45$ & $55.4 \mathrm{aB}$ & $51.3 \mathrm{abcB}$ & $69.8 \mathrm{bcA}$ \\
\hline $45+00+45$ & $58.0 \mathrm{aA}$ & $52.2 \mathrm{abcA}$ & $63.4 \mathrm{cA}$ \\
\hline
\end{tabular}

${ }^{1}$ Means followed by different letters, uppercase in the row and lowercase in the column, differ by Tukey test $(\mathrm{p}<0.05) .{ }^{2}$ Quantity of $\mathrm{N}$ applied as top-dressing in common bean at the phenological stages $\mathrm{V}_{3}$ (formation of first trifoliate leaf), $\mathrm{V}_{4}$ (presence of third trifoliate leaf) and $\mathrm{R}_{5}$ (pre-flowering), respectively.

Higher $\mathrm{N}$ accumulation in succession to $U$. ruziziensis grass compared to maize/U. ruziziensis intercropping and maize as single crop may be related to better synchrony between the $\mathrm{N}$ supply by the straw and the rate of its absorption by the common bean. Kliemann, Braz and Silveira (2006) found in a Latossolo Vermelho distrófico (Oxisol) that the straw of $U$. ruziziensis grass as single crop had a faster decomposition rate ( $8 \%$ higher) than that of maize/U. ruziziensis intercropping until 150 days after desiccation. This observation is consistent with the results obtained in the present experiment, since the period between the desiccation of maize and $U$. ruziziensis grass and the physiological maturity of the common bean was 151 days.

In addition, other studies have verified the importance of the effects of exudates released by the roots of plants of the genus Urochloa on $\mathrm{N}$ cycling, suppressing the nitrification process and reducing $\mathrm{N}$ losses by leaching in agroecosystems (GOPALAKRISHNAN et al., 2009). In the case of this experiment, such benefit of $U$. ruziziensis grass may have been accentuated due to the NTS in consolidation (subject to immobilization) and the use of irrigation (subject to leaching). Although nodulation was not evaluated, the intensity of nodules in the common bean was visually observed in succession to $U$. ruziziensis grass, as single crop or intercropped, with less intensity after maize as single crop, when there was almost no formation of these structures, indicating the need for research on this topic. Thus, it is reinforced that the benefits of $U$. ruziziensis grass in agricultural systems are also related to the improvement of soil microbiology (COSER et al., 2016). In addition, research indicates that $\mathrm{N}$-fertilizer dose and splitting applied at any phenological stage reduce the number and the dry mass of nodules in common bean roots (SOUSA et al., 2020).

On the other hand, although $U$. ruziziensis grass improved the $\mathrm{N}$ nutrition of the common bean in succession, its intercropping with maize did not lead to greater $\mathrm{N}$ accumulation in the common bean compared to maize as single crop (Table 3). Although the straw from maize as single crop frequently has higher $\mathrm{C} / \mathrm{N}$ ratio (AMARAL et al., 2016) and lower $\mathrm{N}$ accumulation (CARMEIS FILHO et al., 2016), compared to the straw from the intercropped system, the mineralization processes may be more intense in this plant residue mainly due to its less lignified constitution (CARVALHO et al., 2011), resulting in a similar $\mathrm{N}$ release to that of straw from the intercropping system during the initial stages of the common bean (period of highest $\mathrm{N}$ accumulation). In a study conducted by Amaral et al. (2016) the $\mathrm{C}: \mathrm{N}$ ratio of maize straw was higher than that of $U$. ruziziensis straw, which characterized it as a material of slower and gradual decomposition. 
According to Cantarella et al. (2007), C:N ratio values between 12 and 25 favor mineralization, while values greater than 50 favor immobilization; the balance in the two processes would be achieved with values of $\mathrm{C}: \mathrm{N}$ ratio between 25 and 30 . In addition, Costa et al. (2012) found higher lignin percentage (3\% more) in silages from maize/U. ruziziensis intercropping compared to maize as single crop, which reinforces the idea of lower decomposition and $\mathrm{N}$ release rate in the intercropping. The results of this study corroborate those obtained by Flôres et al. (2017), who found higher $\mathrm{N}$ accumulation in common bean after $U$. ruziziensis grass as single crop, but did not observe significant differences in $\mathrm{N}$ accumulation in the common bean in succession to maize as single crop and its intercropping with $U$. ruziziensis grass. The average accumulations obtained by these same authors were $71.3,78.9$ and $83.2 \mathrm{~kg} \mathrm{ha}^{-1}$ of $\mathrm{N}$ in the common bean after maize as single crop, intercropping and $U$. ruziziensis grass as single crop, respectively, which are higher than those observed in this experiment, which ranged from 50.8 to $67.4,40.8$ to 66.5 , and 63.4 to $88.5 \mathrm{~kg} \mathrm{ha}^{-1}$ of $\mathrm{N}$ in common bean after maize, intercropping and $U$. ruziziensis grass (Table 3), respectively. This may be related to the differences caused by the common bean cultivars used (IAC Imperador and IPR 139).

From the point of view of soil microbiology, the possible difference between these cropping systems (maize as single crop and intercropped with $U$. ruziziensis) regarding the nodulation process in common bean deserves further scientific research. It should be pointed out that the amount of biomass (straw) of $U$. ruziziensis grass from its intercropping with maize is significantly lower compared to that from its single cultivation (AMARAL et al., 2016). Considering that the experimental area was in the fourth consecutive year under NTS with the same cropping systems, this addition of organic material (straw and root) to the soil became even more substantial. Thus, due to the strong correlation between shoot dry mass and root dry mass in $U$. ruziziensis grass (PACHECO et al., 2016), the intensity of the soil processes promoted by the root system of this forage when intercropped can also be affected, leading to non-significant differences in comparison to maize as single crop. On the other hand, maize/U. ruziziensis intercropping makes it viable to implement the NTS because it increases the amount of straw combined with the financial return with the grain, besides improving the physical, chemical and biological attributes of the soil (FIORENTIN et al., 2011; BORGHI et al., 2013).

Farinelli and Lemos (2010) and Perez et al. (2013) point out that studies evaluating the nutritional aspects of common bean, relating them to grain quality according to the management of fertilization in different cropping systems, are scarce. Hence, by analyzing the $\mathrm{N}$ concentration in the grains, it was possible to observe a superiority in the common bean in succession to U. ruziziensis grass as single crop (Table 1), adding protein value to the final product as a consequence of the higher accumulations promoted by this grass in the shoot dry mass. Similarly to what occurred in the shoots, the inclusion of grass in the intercropping did not lead to increments in $\mathrm{N}$ concentration in the grains, corroborating the hypothesis that the benefits of $U$. ruziziensis grass can be attenuated when it is intercropped. However, the results obtained in common bean after $U$. ruziziensis grass as single crop did not differ from those relative to its cultivation in succession to maize as single crop. Although $U$. ruziziensis grass as single crop led to higher $\mathrm{N}$ concentration in common bean grains, there were no differences in yield as a function of the cropping system in the absence of $\mathrm{N}$ and with the single dose applied at $\mathrm{V}_{4}$ (Table 4$)$.

Table 4. Analysis of the interaction between cropping system (CS) and top-dressing nitrogen splitting (NS) for the grain yield of common bean (cv. IPR 139) cultivated in the no-tillage system, Jaboticabal-SP, 2012/13 agricultural year ${ }^{(1)}$.

\begin{tabular}{cccc}
\hline \multirow{2}{*}{ Treatments } & \multicolumn{3}{c}{ Grain yield $\left(\mathrm{kg} \mathrm{h}^{-1}\right)$} \\
\cline { 2 - 4 } & Maize & Intercropping & U. ruziziensis \\
\hline N splitting $^{2}$ & $2936 \mathrm{bA}$ & & $2889 \mathrm{bA}$ \\
$00+00+00$ & $2954 \mathrm{bA}$ & $2966 \mathrm{cA}$ & $2898 \mathrm{bA}$ \\
$00+90+00$ & $3342 \mathrm{abA}$ & $3425 \mathrm{aA}$ & $3149 \mathrm{abB}$ \\
$30+60+00$ & $2947 \mathrm{bB}$ & $3255 \mathrm{abcA}$ & $2891 \mathrm{bB}$ \\
$60+30+00$ & $3365 \mathrm{aA}$ & $3454 \mathrm{aA}$ & $3075 \mathrm{bB}$ \\
$30+00+60$ & $3213 \mathrm{abA}$ & $3184 \mathrm{abcA}$ & $3002 \mathrm{bA}$ \\
$60+00+30$ & $3320 \mathrm{aA}$ & $3096 \mathrm{bcAB}$ & $2915 \mathrm{bB}$ \\
$00+60+30$ & $2938 \mathrm{bA}$ & $3081 \mathrm{bcA}$ & $3152 \mathrm{abA}$ \\
$45+45+00$ & $3391 \mathrm{aA}$ & $3273 \mathrm{abA}$ & $2942 \mathrm{bB}$ \\
$00+45+45$ & $3167 \mathrm{abAB}$ & $2972 \mathrm{cB}$ & $3377 \mathrm{aA}$ \\
$45+00+45$ & & &
\end{tabular}

${ }^{1}$ Means followed by different letters, uppercase in the row and lowercase in the column, differ by Tukey test $(\mathrm{p}<0.05) .{ }^{2}$ Quantity of $\mathrm{N}$ applied as top-dressing in common bean at the phenological stages $\mathrm{V}_{3}$ (formation of first trifoliate leaf), $\mathrm{V}_{4}$ (presence of third trifoliate leaf) and $\mathrm{R}_{5}$ (pre-flowering), respectively. 
Soratto et al. (2013b), studying early N application for the sowing of common bean, also found that its yield was little influenced by the previous cropping system (maize and maize intercropped with $U$. ruziziensis grass). In addition, it should be considered that agricultural systems are complex, which requires a holistic view of the processes and impacts of these agroecosystems (PANKHURST et al., 1995, OLIVEIRA et al., 2016). However, in the splitting schemes 30-60-00, $30-00-60,00-60-30$ and $00-45-45$, this attribute was superior when the common bean was cultivated in succession to maize as single crop and intercropped with $U$. ruziziensis grass. In addition, the splitting scheme 45-00-45 was the only treatment which led to higher grain yield after $U$. ruziziensis grass compared to the other cropping systems. Research indicates that nutrient exports are more related to grain yield than extraction (LEAL et al., 2019). Thus, the results obtained indicate that this treatment (45-00-45) promoted efficiency in the export of $\mathrm{N}$ by the common bean, mainly because the application of this nutrient occurred at the $\mathrm{R}_{5}$ stage, instead of $\mathrm{V}_{4}$.

As a result of the $\mathrm{N}$ concentration and grain yield, there were no differences in the exports of this nutrient as a function of the previous cropping systems, except for the treatments 00-60-30 and 0045-45 (higher exports after maize as single crop) and 45-00-45 (higher export after $U$. ruziziensis grass as single crop) (Table 5), possibly due to the synchronism between the availability of this nutrient and its respective absorption rate (LEAL et al., 2019).

Table 5. Analysis of the interaction between cropping system (CS) and top-dressing nitrogen splitting (NS) for N export to the grains of common bean (cv. IPR 139) cultivated in the no-tillage system, Jaboticabal-SP, 2012/13 agricultural year ${ }^{(1)}$.

\begin{tabular}{cccc}
\hline \multirow{2}{*}{ Treatments } & \multicolumn{3}{c}{ N export to the grains $\left(\mathrm{kg} \mathrm{ha}^{-1}\right)$} \\
\cline { 2 - 4 } & Maize & Intercropping & U. ruziziensis $^{-}$ \\
\hline N splitting $^{2}$ & $82.2 \mathrm{bA}$ & $81.0 \mathrm{bA}$ & $85.0 \mathrm{aA}$ \\
$00+00+00$ & $84.7 \mathrm{bA}$ & $79.5 \mathrm{bA}$ & $83.6 \mathrm{aA}$ \\
$00+90+00$ & $88.0 \mathrm{abA}$ & $91.1 \mathrm{abA}$ & $86.1 \mathrm{aA}$ \\
$30+60+00$ & $86 \mathrm{bA}$ & $85.1 \mathrm{abA}$ & $81.6 \mathrm{aA}$ \\
$60+30+00$ & $90.7 \mathrm{abA}$ & $94.6 \mathrm{aA}$ & $90.4 \mathrm{aA}$ \\
$30+00+60$ & $88.0 \mathrm{abA}$ & $86.2 \mathrm{abA}$ & $85.3 \mathrm{aA}$ \\
$60+00+30$ & $93.0 \mathrm{abA}$ & $85.9 \mathrm{abAB}$ & $82.8 \mathrm{aB}$ \\
$00+60+30$ & $81.5 \mathrm{bA}$ & $84 \mathrm{abA}$ & $87.6 \mathrm{aA}$ \\
$45+45+00$ & $99.9 \mathrm{aA}$ & $88.68 \mathrm{abB}$ & $84.9 \mathrm{aB}$ \\
$00+45+45$ & $85.00 \mathrm{bAB}$ & $80.6 \mathrm{bB}$ & $91.7 \mathrm{aA}$ \\
$45+00+45$ & & &
\end{tabular}

${ }^{1}$ Means followed by different letters, uppercase in the row and lowercase in the column, differ by Tukey test $(\mathrm{p}<0.05) .{ }^{2}$ Quantity of $\mathrm{N}$ applied as top-dressing in common bean at the phenological stages $\mathrm{V}_{3}$ (formation of first trifoliate leaf), $\mathrm{V}_{4}$ (presence of third trifoliate leaf) and $\mathrm{R}_{5}$ (pre-flowering), respectively.

In the splitting schemes 00-60-30 and 00-4545 , the application of part of the $\mathrm{N}$ as top-dressing at more advanced phenological stages of common bean $\left(\mathrm{R}_{5}\right.$ - pre-flowering) led to greater $\mathrm{N}$ export in the grains, mainly after maize as single crop. Soratto et al. (2013a) observed that the rates of $\mathrm{N}$ accumulation in reproductive structures of the common bean were very high from $45 \mathrm{DAE}$, whereas in the vegetative part this process occurs close to $15 \mathrm{DAE}$. Thus, the splitting schemes with top-dressing $\mathrm{N}$ application closer to common bean flowering, especially in succession to cropping systems that promote greater immobilization, may result in higher exports to the grains. Similarly, in this experiment, N was applied as top-dressing, according to each treatment, at 19, 25 and 56 DAE, which correspond to the stages $V_{3}$, $\mathrm{V}_{4}$ and $\mathrm{R}_{5}$ of the common bean, respectively.

The $\mathrm{N}$ splitting schemes in succession to $U$. ruziziensis grass as single crop did not promote differences in the exports of this nutrient, because the mineralization processes occur more intensely and because of the high accumulation in the shoots of the common bean after this system, which may have reduced the probability of responses to $\mathrm{N}$ splitting. However, when the effects of split $\mathrm{N}$ application on the systems with maize as single crop and intercropped with $U$. ruziziensis grass were analyzed, the highest values were observed in the treatments 00-45-45 and 30-00-60, respectively, corroborating the hypothesis that fertilization later in the cycle promotes greater increases in exports. It is also worth pointing out that the application in a single dose at $\mathrm{V}_{4}(00-90-00)$ did not differ from the absence of top-dressing $\mathrm{N}$ (00-00-00), which demonstrates that this practice can be disadvantageous when the goal is to increase $\mathrm{N}$ content in the grains in succession to the studied cropping systems, evidencing the need for adjustments in the recommendations, mainly in the NTS, as suggested by Costa et al. (2014). 


\section{CONCLUSIONS}

Common bean grain yield differs among cropping systems and as a function of top-dressed nitrogen split application. Single cultivation of $U$. ruziziensis grass, compared to maize and its intercropping with $U$. ruziziensis, leads to greater $\mathrm{N}$ accumulation in the shoots of common bean grown in succession. Regardless of the cropping system prior to common bean, top-dressing $\mathrm{N}$ application in single dose of $90 \mathrm{~kg} \mathrm{ha}^{-1}$ at $\mathrm{V}_{4}$ promotes accumulations and exports similar to those found in the absence of $\mathrm{N}$ fertilization. The splitting with topdressing $\mathrm{N}$ application at the $\mathrm{R}_{5}$ stage (pre-flowering) increases the exports of this nutrient in common bean in succession to maize and its intercropping with $U$. ruziziensis grass.

\section{ACKNOWLEDGMENT}

The authors thank the São Paulo Research Foundation (FAPESP), process number 2011/078409, for granting the scholarship to the first author.

\section{REFERENCES}

ALVARES, C. A. et al. Köppen's climate classification map for Brazil. Meteorologische Zeitschrift, 22: 711-728, 2013.

AMARAL, C. B. et al. Produtividade e qualidade do feijoeiro cultivado sobre palhadas de gramíneas e adubado com nitrogênio em plantio direto. Pesquisa Agropecuária Brasileira, 51: 1602-1609, 2016.

AMBROSANO, E. J. et al. Recomendações de adubação e calagem para o Estado de São Paulo. 2. ed. Campinas: Instituto Agronômico, 1997. p. 194 -195. (Boletim técnico, 100).

BORGHI, E. et al. Intercropping time of corn and palisadegrass or guineagrass affecting grain yield and forage production. Crop Science, 53: 629-636, 2013.

BUTENSCHOEN, O; SCHEU, S.; EISENHAUER, $\mathrm{N}$. Interactive effects of warming, soil humidity and plant diversity on litter decomposition and microbial activity. Soil Biology and Biochemistry, 43: 19021907, 2011.

CANTARELLA, H. Nitrogênio. In: NOVAIS, R.F. et al. (Eds.). Fertilidade do Solo. Viçosa, MG: Sociedade Brasileira de Ciência do Solo, 2007. v. 1, cap. 7 , p. $375-470$.

CARMEIS FILHO, A. C. A. et al. Residual nitrogen fertilization effect of common bean production on succeeding corn intercropped with Congo grass. Revista Ceres, 63: 576-583, 2016.

CARVAlHO, A. M. et al. Cover plants with potential use for crop $\square$ livestock integrated systems in the Cerrado region. Pesquisa Agropecuária Brasileira, 46: 1200-1205, 2011.

CERETTA, C. A. et al. Manejo da adubação nitrogenada na sucessão aveia preta/milho, no sistema plantio direto. Revista Brasileira de Ciência do Solo, 26: 163-171, 2002.

COMPANHIA NACIONAL DE ABASTECIMENTO - CONAB. Acompanhamento de safra brasileira: grãos - safra 2019/2020, décimo segundo levantamento. Disponível em: $<$ https://www.conab.gov.br $>$ Acesso em: 30 set. 2020.

COSER, T. R. et al. Soil microbiological properties and available nitrogen for corn in monoculture and intercropped with forage. Pesquisa Agropecuária Brasileira, 51: 1660-1667, 2016.

COSTA, N. R. et al. Acúmulo de macronutrientes e decomposição da palhada de braquiárias em razão da adubação nitrogenada durante e após o consórcio com a cultura do milho. Revista Brasileira de Ciência do Solo, 38: 1223-1233, 2014.

COSTA, P. M. et al. Intercropping of corn, brachiaria grass and leguminous plants: productivity, quality and composition of silages. Revista Brasileira de Zootecnia, 41: 2144-2149, 2012.

FAGERIA, N. K.; MELO, L. C.; OLIVEIRA, J. Nitrogen use efficiency in dry bean genotypes. Journal of Plant Nutrition, 36: 2179-2190, 2013.

FAGERIA, N. K. Nitrogen management in crop production. Boca Raton: CRC Press, 2014. 436 p.

FARINELLI, R.; LEMOS, L. B. Produtividade, eficiência agronômica, características nutricionais e tecnológicas do feijão adubado com nitrogênio em plantio direto e convencional. Bragantia, 69: 165$172,2010$.

FERREIRA, D. F. Sisvar: a computer statistical analysis system. Ciência e Agrotecnologia, 35: 1039-1042, 2011.

FIGUEIREDO, M. A. et al. Nitrogen and molybdenum fertilization and inoculation of common bean with Rhizobium spp. in two oxisols. Acta Scientiarum Agronomy, 38: 85-92, 2016.

FIORENTIN, C. F. et al. Formação e manutenção de 
palhada de gramíneas concomitante à influência da adubação nitrogenada em cobertura no feijoeiro irrigado em sistema de semeadura direta. Bragantia, 70: 917-924, 2011.

FLÔRES, J. A. et al. Agronomic and qualitative traits of common bean as a function of the straw and nitrogen fertilization. Pesquisa Agropecuária Tropical, 47: 195-201, 2017.

GOPALAKRISHNAN, S. et al. Biological nitrification inhibition by Brachiaria humidicola roots varies with soil type and inhibits nitrifying bacteria, but not other major soil microorganisms. Soil Science and Plant Nutrition, 55: 725-733, 2009.

JARDIM, C.A. Parcelamento da adubação nitrogenada em cobertura no feijoeiro em sucessão ao milho e Urochloa ruziziensis em sistema plantio direto. 2013. 57 f. Tese (Doutorado em Agronomia: Área de Concentração em Produção Vegetal) - Universidade Estadual Paulista, Faculdade de Ciências Agrárias e Veterinárias, Jaboticabal, 2013.

KLIEMANN, H. J.; BRAZ, A. J. P. B.; SILVEIRA, P. M. Taxas de decomposição de resíduos de espécies de cobertura em latossolo vermelho distroférrico. Pesquisa Agropecuária Tropical, 36: 21-28, 2006

KLUTHCOUSKI, J. et al. Braquiária na agropecuária brasileira: uma história de sucesso. In: CECCON, G. (Ed.). Consórcio Milho-Braquiária. Brasília, DF: Embrapa, 2013. v. 1, cap. 1, p. 15-23.

LEAL, F. T. et al. Use efficiency and responsivity to nitrogen of common bean cultivars. Ciência e Agrotecnologia, 43: 1-13, 2019.

MAI, M. E. M. et al. Manejo da adubação nitrogenada na sucessão aveia-preta/milho no sistema plantio direto. Pesquisa Agropecuária Brasileira, 38: 125-131, 2003.

MBUTHIA, L. W. et al. Long term tillage, cover crop, and fertilization effects on microbial community structure, activity: implications for soil quality. Soil Biology and Biochemistry, 89: 24-34, 2015.

MINGOTTE, F. L. C. et al. Impact of crop management and no-tillage system on grain and straw yield of maize crop. Cereal Research Communications, 48: 399-407, 2020.

OLIVEIRA, I. P.; THUNG, M. D. T. Nutrição mineral. In: ZIMMERMANN, M.J.O.; ROCHA, M.; YAMADA, T. (Eds.). Cultura do feijoeiro: fatores que afetam a produtividade. Piracicaba, SP POTAFOS, 1988. v. 1, cap. 10, p. 175-212.

OLIVEIRA, P. et al. Response of soil fungi and biological processes to crop residues in no-tillage system. Pesquisa Agropecuária Tropical, 46: 5764, 2016.

PACHECO, L. P. et al. Shoot and root development of brachiaria grass (Urochloa ruziziensis) under different levels of soil density. Australian Journal of Crop Science, 10: 1424-1428, 2016.

PANKHURST, C. E. et al. Evaluation of soil biological properties as potential bioindicators of soil health. Australian Journal of Experimental Agriculture, 35: 1015-1028, 1995.

PAVANI, L. C.; LOPES, A. S.; GALBEIRO, R. B. Manejo da irrigação na cultura do feijoeiro em sistemas plantio direto e convencional. Engenharia Agrícola, 28: 12-21, 2008.

PEREZ, A. A. G. et al. Extração e exportação de nutrientes pelo feijoeiro adubado com nitrogênio, em diferentes tempos de implantação do sistema plantio direto. Revista Brasileira de Ciência do Solo, 37: 1276-1287, 2013.

RAIJ, B. Van.; CANTARELLA, H. Milho para grãos e silagem. In: In: RAIJ, B. Van. et al. (Eds.). Recomendações de adubação e calagem para o Estado de São Paulo. 2. ed. Campinas: Instituto Agronômico, 1997. p. 56-59. (Boletim técnico, 100).

RAIJ, B. van et al. Análise química para avaliação da fertilidade de solos tropicais. 1. ed. Campinas, SP: Instituto Agronômico, 2001. 285 p.

SOIL SURVEY STAFF. Keys to Soil Taxonomy. 12. ed. Washington: Natural Resources Conservation Service, 2014. 360 p.

SORATTO, R. P. et al. Épocas de aplicação de nitrogênio em feijoeiro cultivado após milho solteiro ou consorciado com braquiária. Pesquisa Agropecuária Brasileira, 48: 1351-1359, 2013b.

SORATTO, R. P. et al. Nutrient extraction and exportation by common bean cultivars under different fertilization levels: I - macronutrients. Revista Brasileira de Ciência do Solo, 37: 10271042, 2013a.

SOUSA, M. A. et al. Productivity and Economics of Inoculated Common Bean as Affected by Nitrogen Application at Different Phenological Phases. Journal of Soil Science and Plant Nutrition, 20:1848-1858 2020

SOUZA, J. E. B; FERREIRA, E. P. B. Improving 
sustainability of common bean production systems

byco-inoculating rhizobia and azospirilla.

Agriculture, Ecosystems and Environment, 237:

250-257 251, 2017.

VIERO, F. et al. Management of irrigation and nitrogen fertilizers to reduce ammonia volatilization.

Revista Brasileira de Ciência do Solo, 39: 1737$1743,2015$. 